\title{
Multiple dynamics of financialization in the automotive sector: Ford and Hyundai cases
}

\author{
Multiplas dinâmicas da financeirização na indústria automobilística: \\ casos da Ford e Hyunday
}

\author{
Marcelo José do Carmo ${ }^{1}$ (1), Mário Sacomano Neto 2 (1), Julio Cesar Donadone 2 (1) \\ 'Universidade Federal de São Carlos - UFSCar, Programa de Pós-graduação em Engenharia de Produção - \\ PPGEP, São Carlos, SP, Brasil. E-mail: marcelojosedocarmo77@gmail.com \\ ${ }^{2}$ Departamento de Engenharia de Produção - DEP, Universidade Federal de São Carlos - UFSCar, São Carlos, \\ SP, Brasil. E-mail: msacomano@ufscar.br; julio@dep.ufscar.br
}

How to cite: Carmo, M. J., Sacomano Neto, M., \& Donadone, J. C. (2020). Multiple dynamics of financialization in the automotive sector: Ford and Hyundai cases. Gestão \& Produção, 27(4), e5173. https://doi.org/10.1590/0104-530X5173-20

\begin{abstract}
The financialization process in the automotive sector is growing and has affected the automakers in different ways. In this paper, we propose to study the different dynamics that involve financialization in the automotive sector by comparing Ford and Hyundai cases worldwide. To do this, we used indicators that aim to concretize the economic concept of financialization. They are the following: a comparison between sources of profitability; composition and shareholder acquisitions; business leaders; compensation payments to executives; dividend payments to shareholders; salaries and level of employment. These indicators showed a tendency of financialization in both automakers, but with different incidences in each one of these indicators. They have shown, for example, that while Ford's financial sector is more profitable than its productive sector, Hyundai's two sources of profitability are much more balanced showing significantly smaller differences than Ford's. The employment level indicator showed that while there has been a huge drop in the number of jobs at Ford in recent decades, at Hyundai there has been a reverse movement of expansion and hiring. The aim of this article is to discuss the financialization indicators in these two automakers, contributing to better knowledge about the automotive sector and collaborating with the research agenda of economic sociology and finance.
\end{abstract}

Keywords: Financialization; Automotive industry; Economic sociology and finance.

Resumo: O processo de financeirização no setor automotivo é crescente e atinge as montadoras de maneiras diferentes. Neste artigo nos propomos a estudar as diferentes dinâmicas que envolvem a financeirização no setor automotivo a partir da comparação entre os casos de Ford e Hyundai. Para isso, utilizamos indicadores que buscam concretizar o conceito econômico da financeirização. São eles: comparação entre as fontes de lucratividade; composição acionária; origens dos dirigentes das empresas; pagamento de compensações aos executivos; pagamento de dividendos aos acionistas; salários dos funcionários e nível de emprego. Esses indicadores demonstraram uma tendência de financeirização em ambas as montadoras, porém com incidência diferente em cada um desses indicadores. Mostraram, por exemplo, que enquanto o setor financeiro da Ford é muito mais rentável proporcionalmente do que seu setor produtivo, na Hyundai as duas fontes de lucratividade são bem mais equilibradas, com diferenças bem menores do que as observadas na Ford. $\mathrm{O}$ indicador de nível de emprego mostrou que enquanto

Received Oct. 31, 2018 - Accepted May 14, 2019

Financial support: None.

This is an Open Access article distributed under the terms of the Creative Commons Attribution License, which permits unrestricted use, distribution, and reproduction in any medium, provided the original work is properly cited. 
houve uma queda enorme nos postos de trabalho na Ford nas últimas décadas, na Hyundai vem havendo um movimento inverso, de ampliação e contratações. Queremos com esse artigo debater os indicadores de financeirização nestas duas montadoras, contribuindo para um melhor conhecimento sobre o setor automotivo e colaborando com a agenda de pesquisas da sociologia econômica e das finanças.

Palavras-chave: Financeirização; Setor automotivo; Sociologia econômica e das finanças.

\section{Introduction}

The financialization process in the automotive industry, the economy and society has been taking place for at least thirty years (Froud et al., 2006) and consists of introducing the principles of maximizing shareholder value (Lazonick \& O'Sullivan 2000; Fligstein, 2001; Fligstein \& Shin, 2004; Carmo et al., 2019) the change in corporate control concepts moving from industrial design to financial design (Fligstein, 1990, 1991), and the increasing importance of the financial market and financial institutions in the economy as a whole (Epstein, 2002). This process is considered multidimensional (Van der Zwan, 2014) because it transforms the functioning of economic systems at the macro and micro level, having an impact on at least three aspects: the increase in the significance of the financial sector in relation to the real sector, productive; the transfer of the real sector of income to the financial sector and the increase in income inequality, contributing to wage stagnation (Palley, 2008, p. 1) and in many cases, job insecurity and unemployment.

This paper aimed to analyze the financialization process in the automotive sector based on indicators that we use in two of the largest automakers on a world scale, which are Ford and Hyundai. The former is one of the oldest automakers, founded in 1903, and certainly the oldest to implement serial production, which revolutionized the automotive sector worldwide. For a long time, Ford was one of the great brands and symbols of the power and importance of American capitalism. The latter is much more recent, founded in 1967, and is part of an older family conglomerate, known as chaebol, which is one of the giants of the South Korean economy. Chaebol is a typical family business, but larger and formed by several companies, a group. According to Noble (2010, p. 14) the board of directors is restricted and dominated by members from the Chung family. He states,

[...] there is no movement to promote the separation of ownership and management, and Hyundai Motors and its closest subsidiaries remain a family affair [...] Hyundai Motors depends on just one man, Mong Koo Chung, who alone has the power to control management.

This conglomerate includes companies in the steel industry, shipbuilding, heavy industry, construction, automakers (Hyundai and Kia) and more recently has been adhering to financialization practices, increasing dividend payments to shareholders and constituting a credit card division, insurance, among other financial "products".

The phenomenon of financialization can be broken down into indicators, but the basic agreement between the main authors is that productive activities are increasingly less profitable than financial activities (Froud et al., 2006; Lazonick \& O'Sullivan, 2000; Fligstein, 2001). The first indicator we will use is the comparison between profitability sources at Ford and Hyundai, as this indicator shows the contribution that each segment (productive and financial) has to the business as a whole (Carmo et al., 2019). 
The second indicator used is that of the shareholding composition and shareholding acquisitions of the automakers, which show the growing participation of financial economic groups as their largest shareholders (Carmo et al., 2019). They are gigantic investment funds, banks and insurance companies that are on the list of the automakers' biggest investors.

The result of a complex set of decisions, the third indicator used by us is the dividend payment to shareholders. This reveals enormous pressure from major shareholders and main executives for dividend payments to investors as a mission, which drains all companies' net profits, whether in the form of dividend payments or through share buybacks or stock buybacks, which have become an artificial strategy for valuing companies' share prices. This is another important aspect of financialization (Lazonick \& O'Sullivan, 2000).

The origin and trajectories of directors is another indicator and shows the academic background and career of the main executives of the companies. According to Fligstein (1991), the past educational and professional life of executives and where they went, whether in the world of industry or business and finance, among other areas, says a lot about managers. Financialization is also a mentality through which a continuous search for maximizing value is established, with people "[...] living and dying by the numbers" (Wartzman, 2017, p. 257).

The payment of millionaire compensation to main executives is also an indicator of financialization that we used, and it seems to be a movement oriented so that both shareholders and senior management are satisfied with the results of business activity. Formally, the compensations are linked to performance criteria obtained by the business, but there are authors who suggest that the compensations have nothing to do with performance, but with power within the organization (Bebchuk \& Fried, 2004).

Whether internal power or real performance drives the compensation policy for executives, the fact is that when we compare the total earnings of corporate CEOs with employee salaries, another category of analysis, we see that there is a huge disparity and that every day it increases and it is becoming very different from what happened previously.

Until around the 1970s, executives received fixed salaries of around one million dollars annually, on average, and some more earnings, but nothing significant. In the last few years what we see is that in addition to the fixed salary, which is still not very high, there are spectacular variable gains with stock options and other bonuses, which adds up to a total compensation reaching tens of millions of dollars every year. Meanwhile workers' wages in general are below average wages, at least in the USA (DeNavas-Walt \& Proctor, 2015). Considering these growing disparities, we finished our set of financialization indicators in the automotive sector with the employment indicator. In this regard, there are also different dynamics in the sector. While at Ford, in the last few decades, there has been a progressive decrease in the workforce, at Hyundai the opposite has happened. There is a slow but consistent increase in employment at Hyundai, mainly because of investments in plants installed in countries considered emerging, such as Brazil, Russia, and India, in recent years.

\section{Methodology}

This work is part of the research agenda of economic sociology, which aims to study economic phenomena from an approach that uses the tools from sociology, so economy is immersed in the social structure of society (Granovetter, 1985). Economics 
and society cannot be arbitrarily separated by scientific analysis, but must be taken together, being complementary dimensions of the same social whole (Weber, 2012).

This is qualitative research, consisting of a case study. It has an exploratory character aiming to assign financialization indicators to two companies in the automotive sector, Ford, and Hyundai. The text seeks to understand how the financialization process takes place (Yin, 2001) in these two automakers, which presented different dynamics for each indicator.

The data are secondary and were collected electronically on the Internet from the automotive companies' websites, where we accessed the annual reports of the companies, which contain the sources of profitability, revenues, profits, among other information; financial market sites, such as nasdaq.com and bloomberg.com, which present data on shareholding composition, dividend payments, compensation to executives, etc.; job market sites such as payscale.com, glassdoor.com, careerbliss.com, which provided us with figures on employee salaries; sites such as statista.com, which showed us the number of employees in companies, among other sources of official information, such as the US Department of Commerce, the US Census Bureau, which gave us the average salary for all the North American ethnic groups, for example. Data analysis was based on documentary analysis (Bardin, 1977).

\section{Research results}

\subsection{Comparison between the sources of profitability at Ford and Hyundai}

When analyzing automotive companies, we can make a distinction between the productive and financial branches. The productive branch has support from financial branches to finance the cars to customers. Furthermore, the financial branch is a typical bank, including products, insurers, and other financial services. At Ford, the financial sector is represented by Ford Motor Credit Company LLC and at Hyundai by Hyundai Capital-Card-Life-Commercial.

At Ford, the productive sector has had a profitability proportionally much lower than its financial sector, as can be seen in Table 1. Since 2001, Ford Automotive has lost billions of dollars, while Ford Financial has had excellent returns on revenue that reached $25 \%$ in 2005 . In 2010 , this difference reached ten times, that is, $3.4 \%$ return on revenue from productive activities and $34 \%$ return on revenue from financial activities. Although the absolute numbers are higher in the productive area, we see that there is a significant portion of profitability in terms of financial activities.

Table 1. Ford revenues by sector.

\begin{tabular}{cccccccc}
\hline $\begin{array}{c}\text { Total } \\
\text { revenue }\end{array}$ & $\begin{array}{c}\text { In } \\
\text { billions } \\
\text { of US\$ }\end{array}$ & $\begin{array}{c}\text { Automotive } \\
\text { Sector } \\
\text { Revenues }\end{array}$ & $\begin{array}{c}\text { Profit } \\
\text { before } \\
\text { tax }\end{array}$ & $\begin{array}{c}\text { \% return/ } \\
\text { revenue }\end{array}$ & $\begin{array}{c}\text { Financial } \\
\text { Sector } \\
\text { Revenues }\end{array}$ & $\begin{array}{c}\text { Profit } \\
\text { before } \\
\text { tax }\end{array}$ & $\begin{array}{c}\text { \% return/ } \\
\text { revenue }\end{array}$ \\
\hline $\mathbf{2 0 0 1}$ & $\mathbf{1 6 0 , 5 0 4}$ & 130,736 & $\mathbf{- 8 . 8 5 7}$ & $-\mathbf{6 . 7}$ & 29,768 & 1,438 & $\mathbf{4 . 8}$ \\
\hline $\mathbf{2 0 0 2}$ & $\mathbf{1 6 2 , 2 5 6}$ & 134,273 & $\mathbf{- 1 , 1 5 3}$ & $-\mathbf{- 0 . 8}$ & 27,983 & 2.104 & $\mathbf{7 . 5}$ \\
\hline $\mathbf{2 0 0 3}$ & $\mathbf{1 6 4 , 1 9 6}$ & 138,442 & $\mathbf{- 1 , 9 5 7}$ & $\mathbf{- 1 . 1}$ & 25,754 & 3,327 & $\mathbf{1 3}$ \\
\hline $\mathbf{2 0 0 4}$ & $\mathbf{1 7 1 , 6 4 6}$ & 147,128 & $\mathbf{- 1 5 5}$ & $\mathbf{- 0 . 1}$ & 24,518 & 5.008 & $\mathbf{2 0}$ \\
\hline $\mathbf{2 0 0 5}$ & $\mathbf{1 7 7 , 0 8 9}$ & 153,503 & $\mathbf{- 3 , 8 9 5}$ & $\mathbf{- 2 . 5}$ & 23,586 & 5,891 & $\mathbf{2 5}$ \\
\hline $\mathbf{2 0 0 6}$ & $\mathbf{1 6 0 , 1 2 3}$ & 143,307 & $\mathbf{- 1 7 . 0 1 7}$ & $\mathbf{- 1 1 . 8}$ & 16,816 & 1,966 & $\mathbf{1 2}$ \\
\hline
\end{tabular}


Table 1. Continued...

\begin{tabular}{cccccccc}
\hline $\begin{array}{c}\text { Total } \\
\text { revenue }\end{array}$ & $\begin{array}{c}\text { In } \\
\text { billions } \\
\text { of US } \$\end{array}$ & $\begin{array}{c}\text { Automotive } \\
\text { Sector } \\
\text { Revenues }\end{array}$ & $\begin{array}{c}\text { Profit } \\
\text { before } \\
\text { tax }\end{array}$ & $\begin{array}{c}\text { \% return/ } \\
\text { revenue }\end{array}$ & $\begin{array}{c}\text { Financial } \\
\text { Sector } \\
\text { Revenues }\end{array}$ & $\begin{array}{c}\text { Profit } \\
\text { before } \\
\text { tax }\end{array}$ & $\begin{array}{c}\text { \% return/ } \\
\text { revenue }\end{array}$ \\
\hline $\mathbf{2 0 0 7}$ & $\mathbf{1 7 0 , 5 7 2}$ & 154,379 & $\mathbf{- 5 . 0 8 1}$ & $\mathbf{- 3 . 2}$ & 16,193 & 1,224 & $\mathbf{7 . 5}$ \\
\hline $\mathbf{2 0 0 8}$ & $\mathbf{1 4 5 , 1 1 4}$ & 129,165 & $\mathbf{- 1 1 , 9 1 7}$ & $\mathbf{- 9 . 2}$ & 15.949 & $\mathbf{- 2 . 5 8 1}$ & $\mathbf{- 1 6}$ \\
\hline $\mathbf{2 0 0 9}$ & $\mathbf{1 1 8 , 3 0 8}$ & 105,893 & 1,212 & $\mathbf{1 . 1}$ & 12,415 & 1.814 & $\mathbf{1 4}$ \\
\hline $\mathbf{2 0 1 0}$ & $\mathbf{1 2 8 , 1 2 2}$ & 119.280 & 4,066 & $\mathbf{3 . 4}$ & 8,842 & 3.003 & $\mathbf{3 4}$ \\
\hline $\mathbf{2 0 1 1}$ & $\mathbf{1 3 5 , 6 0 5}$ & 128,168 & 6.215 & $\mathbf{4 . 9}$ & 7.437 & 2,431 & $\mathbf{3 3}$ \\
\hline $\mathbf{2 0 1 2}$ & $\mathbf{1 3 3 , 5 5 9}$ & 126,567 & 5.928 & $\mathbf{4 . 7}$ & 6,992 & 1,710 & $\mathbf{2 5}$ \\
\hline $\mathbf{2 0 1 3}$ & $\mathbf{1 4 6 , 9 1 7}$ & 139,369 & 5.368 & $\mathbf{3 . 8}$ & 7.548 & 1,672 & $\mathbf{2 2}$ \\
\hline $\mathbf{2 0 1 4}$ & $\mathbf{1 4 4 , 0 7 7}$ & 135,782 & 2,548 & $\mathbf{1 . 9}$ & 8.295 & 1,794 & $\mathbf{2 1}$ \\
\hline $\mathbf{2 0 1 5}$ & $\mathbf{1 4 9 , 5 5 8}$ & 140,566 & 8.224 & $\mathbf{5 . 8}$ & 8,992 & 2,028 & $\mathbf{2 2}$ \\
\hline $\mathbf{2 0 1 6}$ & $\mathbf{1 5 1 , 8 0 0}$ & 141,546 & 9,422 & $\mathbf{6 . 6}$ & 10,253 & 1.820 & $\mathbf{1 8}$ \\
\hline $\mathbf{2 0 1 7}$ & $\mathbf{1 5 6 , 7 7 6}$ & 145,653 & 7.259 & $\mathbf{4 . 9}$ & 11,113 & 2,248 & $\mathbf{2 0}$ \\
\hline $\mathbf{2 0 1 8}$ & $\mathbf{1 6 0 , 3 3 8}$ & 148,294 & 5.422 & $\mathbf{3 . 6}$ & 12,018 & 2,627 & $\mathbf{2 2}$ \\
\hline
\end{tabular}

Source: Ford Annual Reports: (Ford Motor Company, 2003, p. 66-67, 2005, p. 54, 2006, p. 49, 2009, p. 74-75, 2012 , p. 63,2014 , p. 27,2015 a, p. 26,2016 , p. 84,2017 , p. 81,2018 , p. 26 and 77 ).

In contrast to its South Korean competitor, this difference is much smaller. Hyundai points to the development of an important financial sector in the total profitability, but its productive sector is one of the most profitable among all major automakers. While at Ford the average profit in the productive area was 4\% between 2010 and 2015, at Hyundai this sector was responsible for an average of $11 \%$ profitability, although with a slight downward trend. Table 2 shows these data.

Table 2. Hyundai revenues by sector.

\begin{tabular}{|c|c|c|c|c|c|c|}
\hline $\begin{array}{l}\text { Hyundai Motor Group } \\
\text { earnings }\end{array}$ & 2010 & 2011 & 2012 & 2013 & 2014 & 2015 \\
\hline \multicolumn{7}{|l|}{$\begin{array}{l}\text { Automotive Sector } \\
\text { Revenues }\end{array}$} \\
\hline Billions of dollars & $98,858^{*}$ & 67,827 & 73,644 & 76,118 & 77,783 & 80,173 \\
\hline Proft before tax & 9,177 & 10,117 & 9.108 & 10,197 & 8.675 & 7.374 \\
\hline$\%$ return on revenue & 9.28 & 14.91 & 12.36 & 13.39 & 11.15 & 9.19 \\
\hline \multicolumn{7}{|c|}{$\begin{array}{l}\text { *Kia included. Average over the last six years: } 11,71 \% \text { per year leading to a } \\
\text { downward trend }\end{array}$} \\
\hline \multicolumn{7}{|c|}{$\begin{array}{l}\text { Financial Sector } \\
\text { Revenues } \\
\text { Hyundai Capital }\end{array}$} \\
\hline Billions of dollars & 2,665 & 3,028 & 3.106 & 2.804 & 2,625 & 2,575 \\
\hline Profit before tax & 0.603 & 0.603 & 0.512 & 0.457 & 0.288 & 0.325 \\
\hline$\%$ return on revenue & 22.62 & 19.91 & 16.48 & 16.29 & 10.86 & 12.62 \\
\hline \multicolumn{7}{|c|}{$\begin{array}{l}\text { Average over the last six years: } 16.46 \% \text { per year, falling, but remaining in } \\
\text { double digits }\end{array}$} \\
\hline \multicolumn{7}{|c|}{$\begin{array}{l}\text { Hyundai Card } \\
\text { revenue }\end{array}$} \\
\hline Billions of dollars & 2,021 & 2,110 & 2,213 & 2,215 & 2,294 & 2,325 \\
\hline Profit before tax & 0.345 & 0.283 & 0.203 & 0.191 & 0.263 & 0.210 \\
\hline$\%$ return on revenue & 17.07 & 13.41 & 9.17 & 8.62 & 11.46 & 9.03 \\
\hline
\end{tabular}


Table 2. Continued...

\begin{tabular}{|c|c|c|c|c|c|c|}
\hline $\begin{array}{c}\text { Hyundai Motor Group } \\
\text { earnings }\end{array}$ & 2010 & 2011 & 2012 & 2013 & 2014 & 2015 \\
\hline \multicolumn{7}{|c|}{ Average over the last six years: $11.46 \%$ per year } \\
\hline \multicolumn{7}{|c|}{ Hyundai Life revenue } \\
\hline Billions of dollars & 0.898 & 1.008 & 0.876 & 0.636 & 0.930 & 1,338 \\
\hline Profit before tax & 0.004 & 0.004 & -0.035 & $-0,035$ & $-0,066$ & -0.042 \\
\hline$\%$ return on revenue & 0.44 & 0.39 & -3.99 & -5 & -7 & -3 \\
\hline \multicolumn{7}{|c|}{ Average over the last six years: $-3,02 \%$ per year } \\
\hline \multicolumn{7}{|l|}{$\begin{array}{l}\text { Hyundai Commercial } \\
\text { revenue }\end{array}$} \\
\hline Billions of dollars & 0.209 & 0.283 & 0.303 & 0.303 & 0.307 & 0.323 \\
\hline Profit before tax & 0.074 & 0.087 & 0.058 & 0.052 & 0.036 & 0.062 \\
\hline$\%$ return on revenue & 35.40 & 30.74 & 19.14 & 17.16 & 11.72 & 19.19 \\
\hline
\end{tabular}

Source: Hyundai (2012, 2014a, b, 2016). Percentage calculations: developed by the authors.

Hyundai has been developing its financial sector since it created a division called Hyundai Capital-Card-Life-Commercial, which, like Ford, represents an important share of the automaker's profits. The commercial division, for example, represented $35 \%$ profitability on revenues in 2010 , falling to $19 \%$ in 2015 , averaging $22 \%$ in these six years. The credit card division gained $17 \%$ in 2010 , but fell to $9 \%$ in 2015 , with an average of $11.4 \%$ in the following six years. The Hyundai Capital division profited $22 \%$ in 2010 and $12 \%$ in 2015 , an average of $16 \%$. All financial divisions were more profitable than the productive sector. The only division that has been making a loss is life insurance, Hyundai Life, showing a negative average of $3 \%$ in the last six years.

As mentioned earlier, although the financial sector is superior to the productive sector in terms of profitability at Ford and Hyundai, there is a much greater difference between the sectors at Ford, which suggests that this financialization indicator is stronger at Ford than at Hyundai. If we could summarize financialization by this indicator alone, we would say that Ford is much more financialized than Hyundai. When we analyze the contribution that each sector makes to the total business at Ford and Hyundai what we see is that at Ford, the financial sector was fundamental for the business not to go bankrupt. Table 3 shows how much each sector contributed to the overall Ford business, from 1988 to 2015.

Table 3. Contribution of each sector to the business at Ford.

\begin{tabular}{ccccccc}
\hline & \multicolumn{2}{c}{ Contribution from Ford Automotive } & & \multicolumn{2}{c}{ Ford Financial Contribution } \\
\cline { 2 - 3 } \cline { 6 - 6 } \cline { 6 - 6 } & \$ Billion & $\%$ & & & \$ Billion & \% \\
\hline 1988 & 11,378 & 87.6 & & 1.604 & 12.4 \\
\hline 1989 & 7.655 & 85.5 & & 1,298 & 14.5 \\
\hline 1990 & 0.387 & 18.4 & & 1,719 & 81.6 \\
\hline 1991 & $\mathbf{- 5 . 4 7 7}$ & $\mathbf{0}$ & & $\mathbf{1 . 9 8}$ & $\mathbf{1 0 0}$ \\
\hline 1992 & $\mathbf{- 2 . 5 6 2}$ & $\mathbf{0}$ & & $\mathbf{2 , 3 9 5}$ & $\mathbf{1 0 0}$ \\
\hline 1993 & 1,645 & 32.3 & & 3,456 & 67.7 \\
\hline 1994 & 7.449 & 68.2 & & 3,468 & 31.8 \\
\hline
\end{tabular}


Table 3. Continued...

\begin{tabular}{|c|c|c|c|c|}
\hline & \multicolumn{2}{|c|}{ Contribution from Ford Automotive } & \multicolumn{2}{|c|}{ Ford Financial Contribution } \\
\hline & \$ Billion & $\%$ & \$ Billion & $\%$ \\
\hline 1995 & 3.825 & 47.2 & 4,276 & 52.8 \\
\hline 1996 & 3,019 & 37.8 & 4,957 & 62.2 \\
\hline 1997 & 8.129 & 64.7 & 4.427 & 35.3 \\
\hline 1998 & 7.86 & 27.4 & 20,829 & 72.6 \\
\hline 1999 & 9,337 & 76.6 & 2,851 & 23.4 \\
\hline 2000 & 5.631 & 64 & 3,172 & 36 \\
\hline 2001 & -9.394 & 0 & 1.509 & 100 \\
\hline 2002 & $-1,181$ & 0 & 2,155 & 100 \\
\hline 2003 & $-1,957$ & 0 & 3,327 & 100 \\
\hline 2004 & -0.155 & 0 & 5 & 100 \\
\hline 2005 & -3.9 & 0 & 5 & 100 \\
\hline 2006 & -17 & 0 & 1,966 & 100 \\
\hline 2007 & -5 & 0 & 1.2 & 100 \\
\hline 2008 & -11.8 & 0 & -2.6 & 0 \\
\hline 2009 & 0.785 & 30 & 1.814 & 70 \\
\hline 2010 & 4,146 & 55 & 3.003 & 45 \\
\hline 2011 & 6.215 & 71.5 & 2,431 & 28.5 \\
\hline 2012 & 5.928 & 77 & 1.71 & 23 \\
\hline 2013 & 5.368 & 77 & 1,672 & 23 \\
\hline 2014 & 2,548 & 59 & 1,794 & 41 \\
\hline 2015 & 8.224 & 80 & 2,028 & 20 \\
\hline
\end{tabular}

Ford Automotive had losses of US $\$ 50.43$ billion in just 8 years from 2001 to 2008 . Source: Froud et al. (2006), from 1988 to 2003, and Ford Motor Company, 2003, p. 66-67, 2005, p. 54, 2006, p. 49, 2009, p. 74-75, 2012, p. 63,2014 , p. $27,2015 a$, p. 26$)$.

As can be seen in Table 3, Ford went through ups and downs regarding the contribution of each sector. From 2001 to 2008, the company's productive sector made losses of around US\$50 billion, while its financial sector profited more than US $\$ 20$ billion in the same period, being responsible for $100 \%$ contribution to the company. Had it not been for the inflow of these funds through financial activities, the company would probably have gone bankrupt. The one who saved the deal was the Ford Credit Company, which had billionaire profits.

At Hyundai, the productive sector has always been responsible for most of the contribution to the business. Table 4 shows the data from 2004 to 2015 . This shows a completely different dynamic than that observed at Ford. The productive sector at Hyundai has always been significant, even in 2006, when it represented its lowest level, $64.48 \%$, leaving a $35.52 \%$ contribution to its financial sector. In the remaining years, this participation in the business always increased and the majority in favor of the company's productive sector, was responsible for $93 \%$ of the contribution to the business in 2015 . 
Table 4. Contribution of each sector to the business at Hyundai.

\begin{tabular}{ccccc}
\hline & $\begin{array}{c}\text { Contribution of } \\
\text { Hyundai Automotive } \\
\text { in billions of dollars }\end{array}$ & $\%$ & $\begin{array}{c}\text { Contribution of } \\
\text { Hyundai financial } \\
\text { in billions of dollars }\end{array}$ & \% \\
\hline 2004 & 2.605 & $\mathbf{8 1 . 2 3}$ & 0.602 & $\mathbf{1 8 . 7 7}$ \\
\hline 2005 & 3,163 & $\mathbf{8 6 . 7 1}$ & 0.485 & $\mathbf{1 3 . 2 9}$ \\
\hline 2006 & 1,410 & $\mathbf{6 4 . 4 8}$ & 0.777 & $\mathbf{3 5 . 5 2}$ \\
\hline 2007 & 2,074 & $\mathbf{7 6 . 9 6}$ & 0.621 & $\mathbf{2 3 . 0 4}$ \\
\hline 2008 & 1,190 & $\mathbf{6 5 . 5 3}$ & 0.626 & $\mathbf{3 4 . 4 7}$ \\
\hline 2009 & 4,759 & $\mathbf{8 6 . 3 4}$ & 0.753 & $\mathbf{1 3 . 6 6}$ \\
\hline 2010 & 9,177 & $\mathbf{8 9 . 9 5}$ & 1,026 & $\mathbf{1 0 . 0 5}$ \\
\hline 2011 & 10,117 & $\mathbf{9 1 . 2}$ & 0.977 & $\mathbf{8 . 8}$ \\
\hline 2012 & 9.108 & $\mathbf{9 2 . 5 1}$ & 0.738 & $\mathbf{7 . 4 9}$ \\
\hline 2013 & 10,197 & $\mathbf{9 3 . 8 8}$ & 0.665 & $\mathbf{6 . 1 2}$ \\
\hline 2014 & 8.675 & $\mathbf{9 4 . 3 4}$ & 0.521 & $\mathbf{5 . 6 6}$ \\
\hline 2015 & 7.374 & $\mathbf{9 3 . 0 1}$ & 0.555 & $\mathbf{6 . 9 9}$ \\
\hline
\end{tabular}

Source: Hyundai annual reports (Hyundai, 2012, 2014a, 2014b, 2016). Hyundai's historical series is smaller than Ford's because of data availability.

According to these data, we can conclude that Ford is much more dependent on its financial sector than Hyundai. At Ford, were it not for the cross subsidy practiced by the company, by which the financial sector helped the productive sector, which was in crisis half the time, shown in our historical series, the automaker would have already succumbed and declared bankruptcy. Meanwhile, Hyundai has developed a much more moderate relationship of dependence on its financial sector, which is on the rise and is very profitable, setting up yet another dynamic of financialization in these two automotive companies.

\subsection{Shareholding composition}

The shareholding composition is an important indicator of the companies' financialization process. At Ford, the largest shareholders are all large groups of investors and financial institutions. Table 5 presents these data. The 15 largest shareholders concentrated $54 \%$ of the company's shares and market value. This is a large shareholding concentration, considering that there are more than twelve hundred institutional investors in the North American automaker.

Table 5. Most Ford shareholders.

\begin{tabular}{lcccc}
\hline & \multicolumn{4}{c}{ Ford's 15 largest shareholders } \\
\cline { 2 - 5 } & Shares & \% & Amount in US \$ & $\%$ \\
\hline Vanguard Group Inc. & $219,797,431$ & 9.44 & $3,110,134,000.00$ & 9.45 \\
\hline Evercore Trust Company, NA & $218,924,994$ & 9.40 & $3,097,789,000.00$ & 9.41 \\
\hline State Street Corp & $152,403,918$ & 6.54 & $2,156,515,000.00$ & 6.55 \\
\hline $\begin{array}{l}\text { Blackrock Institutional Trust } \\
\text { Company, NA }\end{array}$ & $99,585,663$ & 4.27 & $1,409,137,000.00$ & 4.28 \\
\hline $\begin{array}{l}\text { Barrow Hanley Mewhinney \& } \\
\text { Strauss LLC }\end{array}$ & $83,122,740$ & 3.57 & $1,176,187,000.00$ & 3.58 \\
\hline
\end{tabular}


Table 5. Continued...

\begin{tabular}{lcccc}
\hline & \multicolumn{4}{c}{ Ford's 15 largest shareholders } \\
\cline { 2 - 5 } & Shares & $\%$ & Amount in US \$ & $\%$ \\
\hline Wellington Management & $76,998,498$ & 3.30 & $1,089,529,000.00$ & 3.31 \\
Group LLP & $73,899,080$ & 3.17 & $1,045,672,000.00$ & 3.18 \\
\hline Franklin Resources Inc. & $49,559,296$ & 2.12 & $701,264,000.00$ & 2.13 \\
\hline Allianz Asset Management AG & $47,463,547$ & 2.03 & $671,609,000.00$ & 2.03 \\
\hline Loomis Sayles \& Co LP & $43,793,391$ & 1.88 & $619,676,000.00$ & 1.89 \\
\hline Northern Trust Corp & $43,277,751$ & 1.85 & $612,380,000.00$ & 1.86 \\
\hline Bank of America Corp / DE / & $42,445,613$ & 1.82 & $600,605,000.00$ & 1.83 \\
\hline JPMorgan Chase \& Co & $40,895,998$ & 1.75 & $578,678,000.00$ & 1.76 \\
\hline Blackrock Fund Advisors & $38,807,668$ & 1.66 & $549,129,000.00$ & 1.67 \\
\hline The Bank of New York Mellon & $32,808,857$ & 1.40 & $\mathbf{4 6 4 , 2 4 5 , 0 0 0 . 0 0}$ & 1.41 \\
\hline Corp & $\mathbf{1 , 2 6 3 , 7 8 4 , 4 4 5}$ & & $\mathbf{1 7 , 8 8 2 , 5 4 9 , 0 0 0 . 0 0}$ & \\
\hline FMR LLC & & $\mathbf{5 4 . 2 8 \%}$ & & $\mathbf{5 4 . 3 3 \%}$ \\
\hline Totals & & & & \\
\hline
\end{tabular}

Source: Nasdaq (2019).

At Hyundai, the situation is different, as can be seen in Table 6.

Table 6. Major shareholders of Hyundai.

\begin{tabular}{lccc}
\hline & \multicolumn{3}{c}{ 10 largest shareholders of Hyundai } \\
\cline { 2 - 4 } & Shares & $\%$ & Amount in US \$ \\
\hline Hyundai Mobis Co. Ltd. & $45,782,023$ & 20.8 & $5,783,185,145.36$ \\
\hline $\begin{array}{l}\text { National Pension Service of } \\
\text { Korea }\end{array}$ & $16,344,357$ & 7.42 & $2,064,619,176.24$ \\
\hline Hyundai Motor Co. Ltd. & $13,222,314$ & 6.00 & $1,670,242,704.48$ \\
\hline Mong Koo Chung & $11,395,859$ & 5.17 & $1,439,524,908.88$ \\
\hline Eui Sun Chung & $5,017,145$ & 2.28 & $633,765,756.40$ \\
\hline $\begin{array}{l}\text { Capital Research \& Management } \\
\text { Co. (World Investors) }\end{array}$ & $4,128,447$ & 1.87 & $521,505,425.04$ \\
\hline $\begin{array}{l}\text { Templeton Global Advisors } \\
\text { Ltd. }\end{array}$ & $4,043,285$ & 1.84 & $510,747,761.20$ \\
\hline The Vanguard Group, Inc. & $2,837,713$ & 1.29 & $358,459,906.16$ \\
\hline BlackRock Fund Advisors & $2,615,237$ & 1.19 & $330,356,737.84$ \\
\hline $\begin{array}{l}\text { Capital Research \& } \\
\text { Management Co. (Global }\end{array}$ & $2,328,061$ & 1.06 & $294,080,665.52$ \\
Investors) & $\mathbf{1 0 7 , 7 1 4 , 4 4 1}$ & $\mathbf{4 8 . 9 2}$ & $\mathbf{1 3 , 6 0 6 , 4 8 8 , 1 8 7 . 1 2}$ \\
\hline Total & & & \\
\hline
\end{tabular}

Source: Hyundai (2019a, b).

In the South Korean automaker, the largest shareholders are members of the family conglomerate, the so-called chaebol. Hyundai Mobis is the largest shareholder, followed by a pension fund, by the automaker itself and two company executives. It is a quite different ownership structure from Ford, even though there are institutional investors with minority interests. This indicates that the penetration of financial institutions is less at Hyundai than at Ford, which implies different decisions and 
strategies developed by the company, much more independent of financial capital than its North American competitor.

\subsection{Dividend payments to shareholders and share buybacks}

When analyzing dividend payments to shareholders at Ford and Hyundai, we also noticed differences between the two automakers. At Ford, there has been a strong policy of paying dividends to shareholders for a long time. Since 2012, the North American automaker has been paying $100 \%$ of net profit to shareholders, a practice similar to that of the largest companies in the United States. Table 7 illustrates this data. The company not only makes dividend payments, but also share buybacks.

Stock repurchases are when companies buy back their own shares, removing them from the market. Repurchases increase the value of the remaining shares because there are now fewer common shares outstanding and corporate profits can be divided into fewer shares. Repurchases are sometimes an indication that a company realizes that its shares are undervalued, but it is up to the investor to determine whether the company is correct. Companies that are supportive of shareholders can often pay dividends and at the same time carry out share repurchases (Ycharts, 2019).

Additionally, share buybacks tend to increase prices artificially. It is precisely our indication that there is an element of financialization because the idea of valuing the share price without going through production is pursued constantly. On the other hand, we could assume that the production area is increasingly subordinated to the search for maximizing shareholder value, which is an essential element of the financialization process.

Table 7. Net income distributed at Ford.

\begin{tabular}{|c|c|c|c|c|}
\hline $\begin{array}{c}\text { FORD } \\
\text { MOTOR } \\
\text { COMPANY }\end{array}$ & $\begin{array}{l}\text { Net income in } \\
\text { billions of US \$ }\end{array}$ & $\begin{array}{l}\text { Net Income } \\
\text { Applicable to } \\
\text { Ordinary } \\
\text { Shareholders }\end{array}$ & $\begin{array}{c}\text { Stock Buybacks } \\
\text { Stock } \\
\text { Repurchases } \\
\text { Share Buyback } \\
\text { and m billions of } \\
\text { US \$ }\end{array}$ & $\begin{array}{c}\% \text { of net } \\
\text { income } \\
\text { distributed to } \\
\text { shareholders } \\
\text { and } \\
\text { repurchases }\end{array}$ \\
\hline 2008 & $-14,400$ & - & - & - \\
\hline 2009 & 2,599 & 2,599 & $\mathrm{n} / \mathrm{a}$ & 100 \\
\hline 2010 & 7.149 & 7.149 & $\mathrm{n} / \mathrm{a}$ & 100 \\
\hline 2011 & 8.646 & 8.646 & $\mathrm{n} / \mathrm{a}$ & 100 \\
\hline 2012 & 5.613 & 5.613 & $\mathrm{n} / \mathrm{a}$ & 100 \\
\hline 2013 & 11,953 & 11,953 & $\mathrm{n} / \mathrm{a}$ & 100 \\
\hline 2014 & 1,231 & 1,231 & 1,963 & 100 \\
\hline 2015 & 7.373 & 7.373 & $\mathrm{n} / \mathrm{a}$ & 100 \\
\hline 2016 & 4,589 & 4,589 & $\mathrm{n} / \mathrm{a}$ & 100 \\
\hline 2017 & 7,731 & 7,731 & $\mathrm{n} / \mathrm{a}$ & 100 \\
\hline 2018 & 3,677 & 3,677 & $\mathrm{n} / \mathrm{a}$ & 100 \\
\hline
\end{tabular}

Source: Nasdaq (2019), Investor Place (2017) and Ycharts (2019). 
Hyundai, a younger company, has been gradually adhering to the principles of maximizing shareholder value more recently with a much smaller proportion of net profit distributed to investors. Although a small proportion of the profits was distributed, this movement indicates an upward trend in amounts and percentages. If, in 2012, Hyundai distributed $6.1 \%$ of its net profit to shareholders, in 2015 this level increased to $16.8 \%$ of the distributed net profit, as can be seen in Table 8 .

Table 8. Net profit distributed at Hyundai.

\begin{tabular}{lcccc} 
& \multicolumn{4}{c}{ Net income and distribution to shareholders } \\
\cline { 2 - 5 } & $\mathbf{2 0 1 2}$ & $\mathbf{2 0 1 3}$ & $\mathbf{2 0 1 4}$ & $\mathbf{2 0 1 5}$ \\
\hline Net income (billions of US\$) & 7,752 & 7,730 & 6,648 & 5,807 \\
\hline $\begin{array}{l}\text { Value distributed to } \\
\text { shareholders (billions of US\$) }\end{array}$ & 0,471 & 0,483 & 0,739 & 0,976 \\
\hline $\begin{array}{l}\text { \% of net income distributed to } \\
\text { shareholders }\end{array}$ & $\mathbf{6 . 1}$ & $\mathbf{6 . 3}$ & $\mathbf{1 1 . 1}$ & $\mathbf{1 6 . 8 2}$ \\
\hline
\end{tabular}

Source: Hyundai (2019c).

In these four years between 2012 and 2015, dividend distributions to shareholders have almost tripled, in percentage, and more than doubled in absolute values, from US $\$ 471$ million in 2012 to US\$ 976 million in 2015. Moreover, there is still a tendency to substantially increase these distributions, revealing that adherence to the principles of maximizing shareholder value is increasingly present in the South Korean automaker, more incipiently and gradually than at Ford, but the principles that characterize financialization, in our view, can also be found in the Asian manufacturer, although in a much less dominant way.

\subsection{Origin of company managers}

Fligstein (1991) assesses that the educational and professional origin of company managers says a lot about their beliefs and worldviews. The organizational environment that surrounded the training of executives has enormous weight in the constitution of the values and practices of management professionals and this influences the type of decision that will be taken by the manager when carrying out their duties. In the case of Ford, it can be observed in Table 9 that a large part of the company's directors went through financial organizations, which helped to shape its financialized mentality, facilitating decisions in favor of shareholders as a primary mission.

Table 9. Executive analysis.

\begin{tabular}{ll}
\hline \multicolumn{1}{c}{ Origin of Ford Managers - 2015 } \\
\hline Ford Board of Directors officers & $\begin{array}{l}\text { Financial Organizations in which they } \\
\text { participate or participated }\end{array}$ \\
\hline Kimberly A. Casiano & Bank of Scotland - Puerto Rico \\
Director & Mutual of America Capital Management LLC \\
\hline Anthony F. Earley Jr & New York Stock Exchange \\
Compensation Committee Director & Mutual of America Capital Management LLC \\
& Comerica Bank \\
& Comerica Incorporated \\
\hline
\end{tabular}


Table 9. Continued...

\begin{tabular}{ll}
\hline & Origin of Ford Managers - 2015 \\
\hline $\begin{array}{l}\text { Edsel B. Ford II } \\
\text { Director }\end{array}$ & Federal Reserve Bank of Chicago \\
\hline $\begin{array}{l}\text { Richard A. Gephardt } \\
\text { Director }\end{array}$ & ACO Investment Group \\
& New Cycle Capital LLC \\
& Goldman Sachs Pension Practice \\
& American Income Life Insurance Company \\
\hline James P. Hackett & Old Kent Financial Corp. \\
Director & Fifth Third Bank \\
& Northwestern Mutual Life Insurance \\
& Company \\
\hline James H. Hance Jr & Carlyle Group LP \\
Director & Bank of America Corp. \\
\hline William E. Kennard & Grain Capital \\
Director & Staple Street Capital LLC \\
& MetLife Inc \\
& Metropolitan Life Insurance Company \\
\hline Gerald L. Shaheen & North American Chamber of Commerce \\
Chief Executive Officer of the Nominations & AGCO Corp \\
and Governance Council & National City Corporation \\
\hline John Lawson Thornton & Barrick Gold Corporation \\
Director & San Shan Capital Partners \\
& Laura Ashley Holdings PLC \\
& Goldman Sachs Group Inc \\
\hline Sourc:Blomberg &
\end{tabular}

Source: Bloomberg (2019).

From a total of eighteen members of the Board of Directors, at least nine have already participated in financial organizations, banks, insurance companies and investment funds. Hence, it is understandable that their decisions are largely taken in favor of the shareholders, as can be seen in the case of the dividend payments, which were in the order of $100 \%$ of the distributed net income. This is a characteristic of financialization, the development of efforts towards the shareholder, presented as the main actor involved in the business, with precedence to the interests of other groups and people.

At Hyundai, the situation is quite different. Most leaders are economists, accountants and members of civil society who have never participated in financial organizations, which reinforces Fligstein's (1991) thesis on the origin of leaders that speaks volumes about their current conduct. The main leaders are the presidents of Hyundai Motors and Kia Motors, an automaker that is also part of the Hyundai conglomerate. Having only four internal officers, and all members of the same family who control the chaebol, they share the management with five external members, who are part of associations and even have a former president of the Supreme Court of South Korea as a leader. The Table 10 describes the trajectory of the main leaders of Hyundai. 
Table 10. Executive analysis.

\begin{tabular}{|c|c|}
\hline \multicolumn{2}{|r|}{ Origin of Hyundai Managers - 2015} \\
\hline $\begin{array}{l}\text { Hyundai Board of Directors } \\
\text { officers }\end{array}$ & Organizations in which they participate or participated \\
\hline $\begin{array}{l}\text { Mong Koo Chung } \\
\text { President and CEO }\end{array}$ & $\begin{array}{l}\text { Honorary Ph.D. from the National University of Mongolia in } \\
\text { Business Management } \\
\text { President and CEO of Kia Motors Corporation } \\
\text { Vice President of the Korean Federation of Industries }\end{array}$ \\
\hline $\begin{array}{l}\text { Eui Sun Chung } \\
\text { Vice president }\end{array}$ & $\begin{array}{l}\text { MBA at the University of San Francisco } \\
\text { President of Kia Motors }\end{array}$ \\
\hline $\begin{array}{l}\text { Won Hee Lee } \\
\text { Permanent President }\end{array}$ & $\begin{array}{l}\text { Master of Accounting from Western Illinois University } \\
\text { President of Hyundai Motor Company }\end{array}$ \\
\hline $\begin{array}{l}\text { Gap Han Yoon } \\
\text { Permanent President }\end{array}$ & $\begin{array}{l}\text { Graduated from Keimyung University } \\
\text { President of the Hyundai Plant in Ulsan }\end{array}$ \\
\hline $\begin{array}{l}\text { Sung II Nam } \\
\text { External Strategy Director }\end{array}$ & $\begin{array}{l}\text { Ph.D. in Economics from the University of Rochester } \\
\text { President of the Korean Association of Labor and } \\
\text { Economics } \\
\text { Professor of Economics at Sogang University }\end{array}$ \\
\hline $\begin{array}{l}\text { If Bin Oh } \\
\text { External Legal Director }\end{array}$ & $\begin{array}{l}\text { Master of Laws } \\
\text { President of the Supreme Court in Seoul } \\
\text { Lawyer at Dongin Law Group }\end{array}$ \\
\hline $\begin{array}{l}\text { You Jae Yi } \\
\text { External Marketing Director }\end{array}$ & $\begin{array}{l}\text { MBA at Seoul National University } \\
\text { President of the Korean Marketing Association } \\
\text { Professor of Business Administration at Seoul University }\end{array}$ \\
\hline $\begin{array}{l}\text { Dong Kyu Lee } \\
\text { External Legal Director }\end{array}$ & $\begin{array}{l}\text { Adviser to Kim and Chang Law Group } \\
\text { Secretary-General of the Korean Fair-Trade Commission }\end{array}$ \\
\hline $\begin{array}{l}\text { Byung Kook Lee } \\
\text { External Finance Director }\end{array}$ & $\begin{array}{l}\text { Seoul Regional Tax Office Commissioner } \\
\text { President of e-Chon Tax Accounting Corp }\end{array}$ \\
\hline
\end{tabular}

Source: Hyundai. (2019d).

The trajectory of Hyundai executives differs from that of Ford executives due to the lack of participation in financial institutions, which is quite common in the North American automaker. This provenance from the industrial world may give Hyundai a backing and a greater responsibility for executives considering production needs, aiming to balance the productive and financial dimensions of the enterprise so much so that the volume of dividend payments was much lower than at Ford. Due to the predominance of financial institutions in their property rights, for a long time now the financialized mentality and the search for maximizing shareholder value seem to be more common. Hyundai is just beginning its financialization process compared with Ford. The professional trajectories of executives and managers are also one of the indicators of financialization.

\subsection{Compensation to executives}

In this financialization indicator, we present the total compensation to executives at both automakers. At Ford, we collected the total earnings of six executives, ranging from US\$ 4.4 million to US\$ 22 million annually. As Bebchuk \& Fried (2004) pointed out, although there is formally a complex calculation that seeks to determine the total earnings of executives, based on performance, the question of internal power is one of the factors that explains the payment of millionaire compensation to these managers. 
Table 11. Ford. Compensation to executives 2014 in US\$.

\begin{tabular}{|c|c|c|c|c|c|c|}
\hline $\begin{array}{c}\text { Executive } \\
\text { compensation } \\
\text { In US \$ } 2014\end{array}$ & $\begin{array}{l}\text { Mark Fields } \\
\text { CEO }\end{array}$ & $\begin{array}{c}\text { Robert } \\
\text { Shanks } \\
\text { Executive } \\
\text { Vice } \\
\text { President } \\
\text { Chief } \\
\text { Financial } \\
\text { Officer }\end{array}$ & $\begin{array}{c}\text { William } \\
\text { Clay Ford } \\
\text { Jr. } \\
\text { Executive } \\
\text { president }\end{array}$ & $\begin{array}{l}\text { Joseph } \\
\text { Hinrichs } \\
\text { Vice } \\
\text { President; } \\
\text { Ford } \\
\text { Americas } \\
\text { division } \\
\text { president }\end{array}$ & $\begin{array}{l}\text { James D. } \\
\text { Farley Jr. } \\
\text { Vice } \\
\text { President; } \\
\text { Ford } \\
\text { Europe } \\
\text { division } \\
\text { president, } \\
\text { Middle } \\
\text { East, } \\
\text { Africa }\end{array}$ & $\begin{array}{c}\text { Alan } \\
\text { Mulally } \\
\text { Former } \\
\text { President } \\
\text { and Former } \\
\text { CEO }\end{array}$ \\
\hline Salary & $1,662,500$ & 798,750 & $2,000,000$ & 936,250 & 868,750 & $1,000,000$ \\
\hline Bonus & 0.00 & 267,450 & 0.00 & 135,000 & 0.00 & 0.00 \\
\hline Share award & $3,412,489$ & $2,183,995$ & $4,777,493$ & $2,183,995$ & $1,979,244$ & $10,237,495$ \\
\hline Stock options & $6,249,994$ & 799,995 & $1,749,996$ & 799,995 & 724,994 & $3,749,994$ \\
\hline $\begin{array}{l}\text { Non-equity } \\
\text { incentive plan }\end{array}$ & $3,185,000$ & 732,550 & 910,000 & 910,000 & 800,000 & $3,185,000$ \\
\hline $\begin{array}{l}\text { Change in } \\
\text { pension value } \\
\text { and profit not } \\
\text { qualified } \\
\text { deferred } \\
\text { compensation }\end{array}$ & $3,647,336$ & $1,454,163$ & $4,427,336$ & $1,048,145$ & 0.00 & 0.00 \\
\hline $\begin{array}{l}\text { Other } \\
\text { compensation }\end{array}$ & 439,178 & 83,743 & $1,245,870$ & 79,245 & 121,776 & $3,869,639$ \\
\hline $\begin{array}{l}\text { Total } \\
\text { Compensation }\end{array}$ & $18,596,497$ & $6,320,646$ & $15,110,695$ & $6,092,630$ & $4,494,764$ & $22,042,128$ \\
\hline
\end{tabular}

Source: Ford Motor Company (2015b, p. 58).

It can be observed in Table 11 that the amounts paid in salary are small in relation to the total compensation, around $15 \%$, reaching only $5 \%$ in the case of Alan Mulally, former CEO, and director, who earned US\$ 1 million in salary and US\$22 million in total compensation in 2014. This is yet more proof of the financialization process, which aims to create a layer of millionaire executives, more through stock payments and other awards and less in the form of wages. Even more, for these executives, the income tax will be charged only on the salary and the other earnings will be prone to lower taxation.

At Hyundai, only in this financialization indicator is there an equivalence with Ford. Hyundai executives also received millionaire amounts, reaching US\$ 12 million received by CEO Mong Koo Chung in 2014. The data for the remaining executives are not available, given that the South Korean automaker has only recently been revealing figures to respect the transparency rules required by publicly traded companies. However, the data we have leads us to conclude that they are moving quickly towards joining the international group of companies that pay millionaire compensation to their executives.

Table 12 shows the little data we were able to obtain on the total earnings of Hyundai executives. 
Table 12. Hyundai.

\begin{tabular}{|c|c|}
\hline Board of Directors & $\begin{array}{c}\text { Compensation paid to executives } \\
\text { Annual in US\$ in } 2014\end{array}$ \\
\hline $\begin{array}{l}\text { Mong Koo Chung } \\
\text { President }\end{array}$ & $\begin{array}{c}\text { 4,907,975.00 - Hyundai Motors } \\
\text { 3,680,981.00 - Hyundai Mobis } \\
\text { 3,680,981.00 - Hyundai Steel } \\
\text { 12,269,937. 00: total earnings }\end{array}$ \\
\hline $\begin{array}{l}\text { Eui Sun Chung } \\
\text { Vice president }\end{array}$ & $\begin{array}{c}\text { 1,628,959.27 - Hyundai Motors } \\
542,986.42 \text { - Hyundai Mobis } \\
\text { n / a - Hyundai Steel } \\
\text { n / a - Kia Motors }\end{array}$ \\
\hline $\begin{array}{c}\text { Won Hee Lee } \\
\text { Permanent President }\end{array}$ & $\mathrm{n} / \mathrm{a}$ \\
\hline $\begin{array}{c}\text { Gap Han Yoon } \\
\text { Permanent President }\end{array}$ & $\mathrm{n} / \mathrm{a}$ \\
\hline
\end{tabular}

Source: Kim (2014).

CEO Mong Koo Chung receives US\$ 4.9 million for his work at three chaebol companies, Hyundai Motors; Hyundai Mobis US\$ 3.6 million and Hyundai Steel, another US\$ 3.6 million, resulting in US\$ 12.2 million in 2014, an amount approximately those paid to Ford executives.

\subsection{Employee salaries}

This indicator analyzes the salary of employees at Ford and Hyundai. Table 13 shows some professions in the North American automaker and it can be seen that most workers, who are service assistants, assemblers and administrative assistants have a low salary as soon as they are hired, which ranges from US $\$ 17,000$ to US $\$ 25,000$ annually, well below the average wages for all North American ethnic groups, which stood at US $\$ 53,000$ annually (DeNavas-Walt \& Proctor, 2015, p. 5).

Table 13. Ford.

\begin{tabular}{lcc}
\hline & \multicolumn{2}{c}{$\begin{array}{c}\text { Annual Employee Salaries } \\
\text { in US\$ - August / 2015 }\end{array}$} \\
\cline { 2 - 3 } Service Assistant & \multicolumn{2}{c}{ Max. } \\
\hline Administrative assistant & $17,881.00$ & $57,320.00$ \\
\hline Fitter & $24,834.00$ & $46,801.00$ \\
\hline Electrical engineer & $25,907.00$ & $68,086.00$ \\
\hline Supervisor Engineer & $67,917.00$ & $147,559.00$ \\
\hline Group Manager of Engineers & $64,535.00$ & $154,628.00$ \\
\hline
\end{tabular}

Source: Payscale (2015).

Only over time is there a progressive increase in wages, but nothing much more than the average of workers in general, in a sector that has always had good pay as a differential between professions. Today there is a clear process of downgrading salaries in this sector, in which many professionals' salaries are well below the average 
salaries for all North American ethnic groups, US\$ 53,000 annually in 2014 (DeNavasWalt \& Proctor, 2015, p. 5).

We did not find the salaries of Hyundai assemblers in South Korea; however, we did find average salaries for Americans which start at US\$52,000. When we look at the amount paid to the R\&D Engineer in South Korea, the salary starts at US\$30,700, a ratio of $60 \%$ of the salary of an assembler at Hyundai in the USA, which leads us to believe that an assembler in South Korea is expected to earn even less, as the R\&D Engineer starts at the US $\$ 30,000$ range. We may see in Table 14 below.

Table 14. Hyundai.

\begin{tabular}{|c|c|c|}
\hline & \multicolumn{2}{|c|}{$\begin{array}{l}\text { Annual wages of employees } \\
\text { in US\$ - } 2016\end{array}$} \\
\hline & Min. & Max. \\
\hline R\&D Engineer - South Korea & $30,700.00$ & $63,300.00$ \\
\hline Management Assistant - South Korea & $49,400.00$ & $53,100.00$ \\
\hline Senior Research Manager - South Korea & $58,800.00$ & $82,200.00$ \\
\hline Assembler -USA / Alabama & $52,000.00$ & $56,000.00$ \\
\hline Process Engineer - USA / Alabama & $57,000.00$ & $63,000.00$ \\
\hline Hired by the hour - Alabama - & 9.00 & 10.00 \\
\hline Process Control Specialist - Alabama & $52,000.00$ & $57,000.00$ \\
\hline Mechanical Engineer - India & Average & $96,000.00$ \\
\hline Sales Manager - India & Average & $218,000.00$ \\
\hline Quality Engineer - China & $140,278.32$ & $149,270.52$ \\
\hline
\end{tabular}

Source: Glassdoor (2015, 2019a, b), Payscale (2019) and Careerbliss (2019).

\subsection{Relationship between employee salaries and total CEO earnings}

When compared with the total earnings of the CEOs, workers' salaries show a real gap between the income ranges, reaching 1040 times the difference between the earnings of the CEO and a service assistant at Ford, for example. The ratio between the earnings of the CEO and an assembler is at least 495 times, as shown in Table 15.

Table 15. Ford.

\begin{tabular}{lccc}
\hline & \multicolumn{3}{c}{$\begin{array}{c}\text { The ratio of times between employee } \\
\text { salaries and CEO 2014 total earnings }\end{array}$} \\
\cline { 2 - 4 } & Min. & Max. & Average \\
\hline Service Assistant & 324 & 1040 & 682 \\
\hline Administrative assistant & 397 & 748 & 572 \\
\hline Fitter & 273 & 717 & 495 \\
\hline Electrical engineer & 126 & 273 & 199 \\
\hline Supervisor Engineer & 120 & 288 & 204 \\
\hline Manager of Engineering Group & 97 & 205 & 151 \\
\hline
\end{tabular}

Source: Author, based on the comparison of the data in the Table 11 "Total compensation to directors and officers (annual)" and Table 13 "Employee salaries - annual in US\$". 
At Hyundai, the relationship is similar, with disparities between the total earnings of the CEO and one hired per hour in Alabama, USA, reaching 555 times. In the same US state, there is a difference between the CEO's total earnings of 222 times, on average. At Hyundai, there are also huge differences between the income brackets, showing a similar process in the two automakers, as we can see in Table 16.

Table 16. Hyundai.

The ratio of times between employee salaries and CEO 2014 total earnings

\begin{tabular}{lccc} 
& Min. & Max. & Average \\
\hline R\&D Engineer - South Korea & 390 & 189 & 289 \\
\hline Management Assistant - South Korea & 242 & 225 & 233 \\
\hline Senior Research Manager - South Korea & 204 & 145 & 174 \\
\hline Assembly line worker - Alabama & 230 & 214 & 222 \\
\hline Process Engineer - Alabama & 210 & 190 & 200 \\
\hline Hired by the hour - Alabama & 555 & 500 & 527 \\
\hline Process Control Specialist - Alabama & 230 & 210 & 220 \\
\hline Mechanical Engineer - India & $\mathrm{n} / \mathrm{a}$ & $\mathrm{n} / \mathrm{a}$ & 125 \\
\hline Sales Manager - India & $\mathrm{n} / \mathrm{a}$ & $\mathrm{n} / \mathrm{a}$ & 55 \\
\hline Quality Engineer - China & 87 & 82 & 85 \\
\hline
\end{tabular}

Author based on the comparison of the data in the Table 12 "Total compensation to directors and officers (annual)" and Table 14 "Employee salaries - annual".

\subsection{Employment}

The last indicator of financialization that we use in this work is employment, and here we see a fundamental difference in dynamics between Ford and Hyundai. At Ford, there has been a tendency to cut jobs over the past 15 years, from more than 350,000 workers in 2001 to 199,000 in 2015, a drop of more than $40 \%$ (Graph 1).

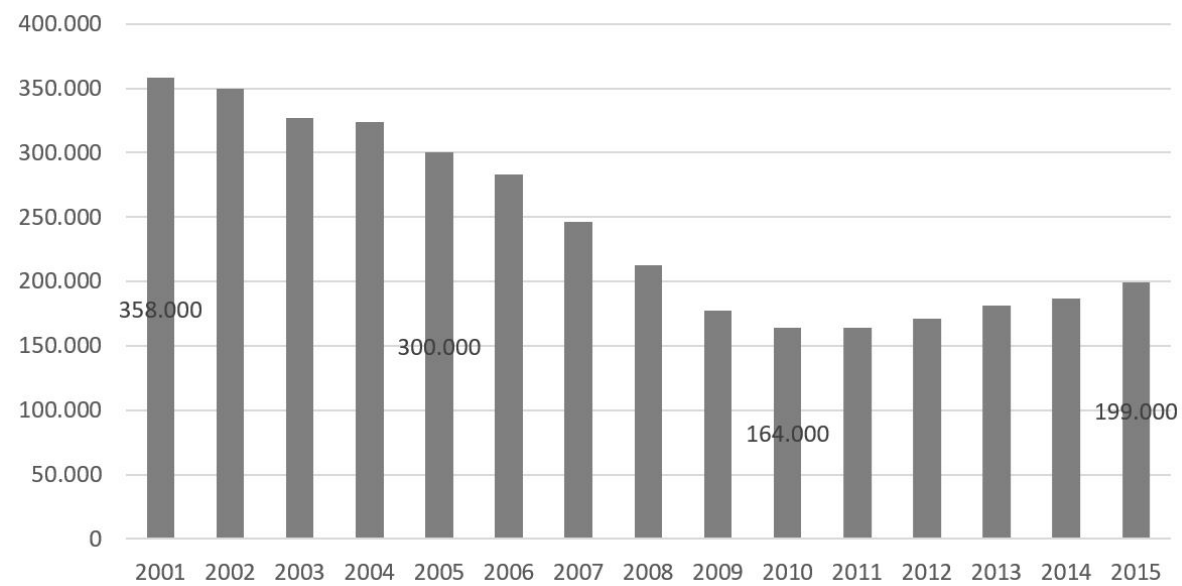

Graph 1. Ford - Employment evolution in thousands of workers. Source: Ford Annual Reports (Ford Motor Company, 2002, 2003, 2004, 2005, 2006, 2007, 2008, 2009, 2010, 2011, 2012, 2013, 2014, 2015a, 2016), section employment data. In the 2016 annual report, p. 10 (Ford Motor Company, 2016). 
At Hyundai, the trend is the opposite, with a consistent increase in the workforce, due to increased demand and the growth of the South Korean automaker's share in the world market. We were unable to survey a historical series that was broader, going back more in time. Due to a lack of this data, we only managed to analyze four years, from 2013 to 2016. Nevertheless, it is sufficient for our study, which is to detect observes the trends and employment dynamics in that automaker. Graph 2 shows the data.

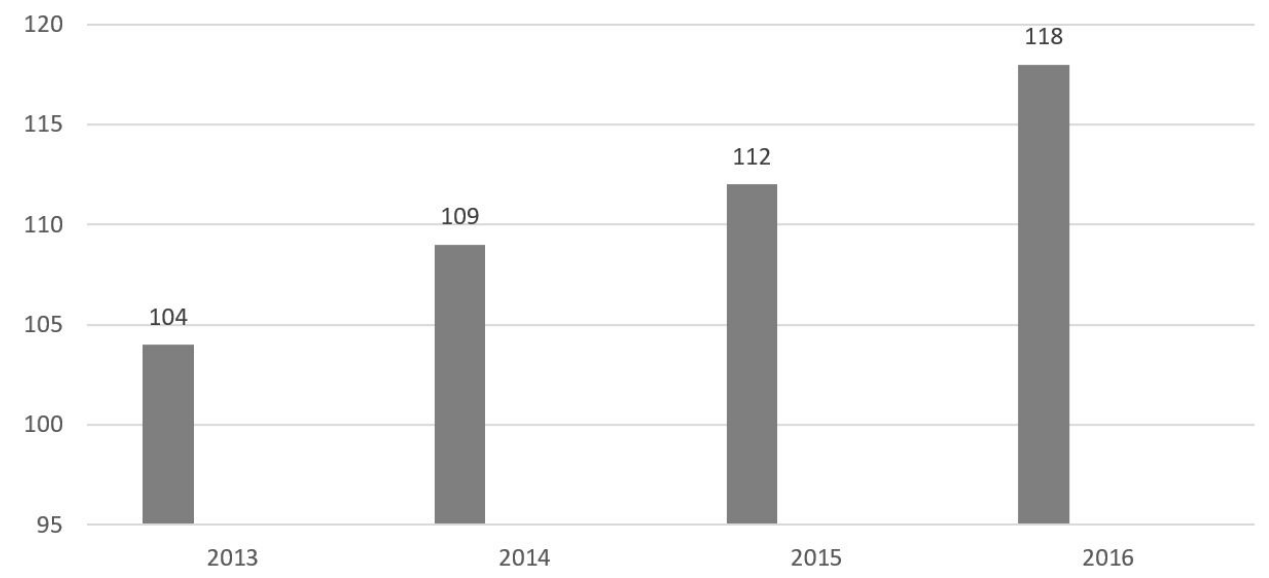

Graph 2. Hyundai - Employment evolution in thousands of workers. Source: Hyundai (2019e).

As already mentioned, employment at Hyundai increased, while at Ford it decreased, even with positive fluctuations in North America from 2010 to 2015. It can be clearly seen that there was a decrease in the workforce and, in Hyundai, the movement was the opposite, as hiring took place and plants were opened in countries considered emerging, such as Brazil, India, and Russia.

\section{Conclusions}

It can be concluded that the financialization process in the automotive sector does not occur in the same way in all the automakers. There are different dynamics between Ford and Hyundai, for example, which were discussed in this article.

Our financialization indicators showed more differences than similarities in these two automakers. The first refers to the comparison between the sources of profitability in companies. The difference between the productive and financial areas of the automakers is clear and the financial area had a clear advantage in both automakers. This difference is much greater at Ford than at Hyundai, reaching five times more, on average. At Hyundai, the difference is less than double, considering the card, capital, and commercial divisions of the South Korean automaker. It is a sign that Ford depends much more on its financial area than Hyundai, which shows that the North American company is much more financialized than the Asian one in terms of this indicator.

In the shareholding indicator we see that Ford has most of its institutional investors, large groups and financial institutions in its property rights, unlike Hyundai, whose largest investors are companies that are part of the family conglomerate, the well-known chaebol, as well as a pension fund and the managers themselves. Institutional investors do not hold most of the shares, as is the case at Ford. The origin of the 
directors reveals different professional backgrounds and different job experiences. For example, in Ford many executives had their trajectory related to the financial market. At Hyundai, they all come from industries and civil society.

The dividend payments to shareholders showed that the maximization of shareholder value is much more present at Ford with $100 \%$ of the net profit distributed, while at Hyundai this process is more recent, tending to increase, but at a different pace than at Ford. The compensation paid to the executives found a similarity between the two automakers, in which payments at Ford were known for a long time and at Hyundai the data is only now being made available. In both, there are millionaire gains on the part of the executives.

Salaries at both automakers are below the average level in the United States. In South Korea we did not find enough data for a better comparison, but the data we have leads us to conclude that both at Ford and Hyundai there is a flattening of the salary process and when compared to the total earnings of the CEOs, they show a gap between the income brackets in the automakers. Employment in each of the automakers also showed different dynamics: while there is a downward trend at Ford, there is an upward trend at Hyundai. There are inverted movements in automakers with vastly different histories.

Finally, this work aimed to better understand the financialization process in the automotive sector, based on the comparison between the two automakers. We hope to have contributed to the research agenda of economic sociology and finance.

\section{Acknowledgements}

We are grateful to Capes, who has financed the student Marcelo José do Carmo, through a master's scholarship, and one of the results was this scientific article.

\section{References}

Bardin, L. (1977). Content analysis. Lisbon: Editions 70.

Bebchuk, L. A., \& Fried, J. M. (2004). Pay without performance, the unfulfilled promise of executive compensation. Part II: power and pay (Draft of the book "Pay without performance: the unfulfilled promise of executive compensation"). Cambridge: Harvard Law School.

Bloomberg. (2019). Retrieved in 2019, June 30, from http://www.bloomberg.com/research/stocks/people/person.asp?personld=176639\&privcapl $d=106335$

Careerbliss. (2019). Retrieved in 2019, June 30, from https://www.careerbliss.com/hyundaimotors/salaries/assemblylineworker

Carmo, M. J., Sacomano, M., No., \& Donadone, J. C. (2019). Financialization in the automotive industry: shareholders, managers, and salaries. Journal of Economic Issues, 53(3), 841862. http://dx.doi.org/10.1080/00213624.2019.1646609.

DeNavas-Walt, C., \& Proctor, B. D. (2015). Income and poverty in the United States: 2014. Current population reports. Washington: US Census Bureau. Retrieved in 2019, June 30, from https://www.census.gov/content/dam/Census/library/publications/2015/demo/p60252.pdf

Epstein, G. (2002). Financialization, rentier interest, and central bank policy. In PERI Conference on "Financialization of the World Economy. Amherst: University of Massachusetts. 
Fligstein, N. (1990). The transformation of corporate control. Cambridge: Harvard University Press.

Fligstein, N. (1991). The structural transformation of the American industry: an institutional account of the causes of diversification in the largest firms, 1919-1979. In P. J. DiMaggio \& W. W. Powell (Eds.), The new institutionalism in organizational analysis (pp. 311-336). Chicago: University of Chicago Press.

Fligstein, N. (2001). The architecture of markets: an economic sociology of twenty-first-century capitalist societies. Princeton: Princeton University Press. http://dx.doi.org/10.1515/9780691186269.

Fligstein, N., \& Shin, T. (2004). Shareholder value and the transformation of the American economy, 1984-2001 (Project "The New Inequalities at Work", pp. 1-55). Berkeley: Department of Sociology, University of California.

Ford Motor Company. (2002). Ford Motor Company 2002 annual report. Detroit. Ford Motor Company. (2003). Ford Motor Company 2003 annual report. Detroit. Ford Motor Company. (2004). Ford Motor Company 2004 annual report. Detroit. Ford Motor Company. (2005). Ford Motor Company 2005 annual report. Detroit. Ford Motor Company. (2006). Ford Motor Company 2006 annual report. Detroit. Ford Motor Company. (2007). Ford Motor Company 2007 annual report. Detroit. Ford Motor Company. (2008). Ford Motor Company 2008 annual report. Detroit. Ford Motor Company. (2009). Ford Motor Company 2009 annual report. Detroit. Ford Motor Company. (2010). Ford Motor Company 2010 annual report. Detroit. Ford Motor Company. (2011). Ford Motor Company 2011 annual report. Detroit. Ford Motor Company. (2012). Ford Motor Company 2012 annual report. Detroit. Ford Motor Company. (2013). Ford Motor Company 2013 annual report. Detroit.

Ford Motor Company. (2014). Ford Motor Company 2014 annual report. Retrieved in 2019, June 30, from https://s22.q4cdn.com/857684434/files/doc_financials/2014/annual/f-12-312014-10-k.pdf

Ford Motor Company. (2015a). Ford Motor Company 2015 annual report. Retrieved in 2019, June 30, from https://corporate.ford.com/content/dam/corporate/en/investors/reports-andfilings/Annual\%20Reports/2015-Annual-Report.pdf

Ford Motor Company. (2015b). Proxy statement. Retrieved in 2019, June 30, from https://corporate.ford.com/content/dam/corporate/en/investors/reports-andfilings/Proxy\%20Statements/2015-ford-proxy-statement.pdf

Ford Motor Company. (2016). Ford Motor Company 2016 annual report (pp. 10). Detroit.

Ford Motor Company. (2017). Ford Motor Company 2017 annual report. Detroit.

Ford Motor Company. (2018). Ford Motor Company 2018 annual report. Detroit.

Froud, J., Johal, S., Leaver, A., \& Williams, K. (2006). Financialization \& strategy: narrative and numbers. London: Routledge. http://dx.doi.org/10.4324/9780203414941.

Glassdoor. (2015). Retrieved in 2019, June 30, from https://www.glassdoor.com/Salary/HyundaiMotorManufacturingAlabamaSalariesE39713.htm

Glassdoor. (2019a). Hyundai Motor salaries. Retrieved in 2019, June 30, from https://www.glassdoor.com/Salary/Hyundai-South-Korea-SalariesEl_IE7474.0,7_IL.8,19_IN135.htm

Glassdoor. (2019b). Retrieved in 2019, June 30, from https://www.glassdoor.com/Salary/Hyundai-China-SalariesEl_IE7474.0,7_IL.8,13_IN48.htm

Granovetter, M. (1985). Economic action and social structure: the problem of embeddedness. American Journal of Sociology, 91(3), 481-510. http://dx.doi.org/10.1086/228311. 
Hyundai. (2012). Hyundai annual report 2012 (pp. 72). Retrieved in 2019, June 30, from http://worldwide.hyundai.com/WW/Corporate/InvestorRelations/Corporatelnformation/BOD/ Shareholders/index.html

Hyundai. (2014a). Hyundai annual report 2014 (pp. 3-7). Seul.

Hyundai. (2014b). Hyundai card-life-capital-commercial annual report 2014 (pp. 12-16). Seul.

Hyundai. (2016). Annual report 2016 (pp. 22-35). Seul.

Hyundai. (2019a). Shareholders. Retrieved in 2019, June 30, from http://worldwide.hyundai.com/WW/Corporate/InvestorRelations/Corporatelnformation/BOD/ Shareholders/index.html

Hyundai. (2019b). Hyundai Motor Company (A005380). Retrieved in 2019, June 30, from http://www.4-traders.com/HYUNDAI-MOTOR-CO-6492384/company/

Hyundai. (2019c). Dividend history. Retrieved in 2019, June 30, from http://worldwide.hyundai.com/WW/Corporate/InvestorRelations/StockInformation/Dividendh istory/index.html

Hyundai. (2019d). Board of directors. Retrieved in 2019, June 30, from http://worldwide.hyundai.com/WW/Corporate/InvestorRelations/Corporatelnformation/BOD/ BoardofDirectors/index.html

Hyundai. (2019e). About sustainability. Retrieved in 2019, June 30, from https://www.hyundai.com/worldwide/en/about-hyundai/csr/sustainabilitymanagement/social/employees

Investor Place. (2017). Retrieved in 2019, June 30, from https://investorplace.com/2017/07/fordmotor-company-f-stock-is-cheap-so-why-no-buybacks/

Kim, R. (2014). Hyundai motor reveals chairman's pay for first time. Bloomberg. Retrieved in 2019, June 30, from http://www.bloomberg.com/news/articles/2014-03-31/hyundai-motorreveals-chairman-s-pay-for-first-time

Lazonick, W., \& O'Sullivan, M. (2000). Maximizing shareholder value: a new ideology for corporate governance. Economy and Society, 29(1), 13-35. http://dx.doi.org/10.1080/030851400360541.

Nasdaq. (2019). F institutional holdings. Retrieved in 2019, June 30, from http://www.nasdaq.com/symbol/f/institutional-holdings

Noble, G. W. (2010). Fordism light: Hyundai's challenge to coordinated capitalism (BRIE Working Paper, No. 186). Tokyo: Institute of Social Science, University of Tokyo.

Palley, T. I. (2008). Financialization: what it is and why it matters (IMK Working Paper, No. 4). New York: The Levy Economics Institute.

Payscale. (2015). Average Ford Motor Company salary. Retrieved in 2019, June 30, from http://www.payscale.com/research/US/Employer=Ford_Motor_Company/Salary/by_Job

Payscale. (2019). Average Hyundai Motor India Ltd salary in India. Retrieved in 2019, June 30, from http://www.payscale.com/research/IN/Employer=Hyundai_Motor_India_Ltd/Salary

Van der Zwan, N. (2014). Making sense of financialization. Socio-economic Review, 12(1), 99129. http://dx.doi.org/10.1093/ser/mwt020.

Wartzman, R. (2017). The end of loyalty: the rise and fall of good jobs in America. New York: PublicAffairs.

Weber, M. (2012). Economy and society: fundamentals of comprehensive sociology (4th ed.). Brasília: UnB.

Ycharts. (2019). Stock buyback. Retrieved in 2019, June 30, from https://ycharts.com/glossary/terms/stock_buyback

Yin, R. K. (2001). Case study: planning and methods (2nd ed.). Porto Alegre: Bookman. 